\title{
Growth performance, morphometric analysis of the intestinal mucosa and thyroid of broiler fed canola meal
}

\author{
[Desempenho e análise morfométrica da mucosa intestinal e da tireoide de frangos de corte \\ alimentados com farelo de canola] \\ P.O. Moraes ${ }^{1}$, L. Novelini ${ }^{2}$, E.L. Krabbe ${ }^{3}$, V.L. Kawski ${ }^{3}$, J.K. Nunes ${ }^{4}$, C.D. Corcini ${ }^{2}$, \\ A.S. Varella ${ }^{5}$, E.G. Xavier ${ }^{2}$ \\ ${ }^{1}$ Universidade Federal do Rio Grande do Sul - Porto alegre, RS \\ ${ }^{2}$ Universidade Federal de Pelotas - Pelotas, RS \\ ${ }^{3}$ Empresa Brasileira de Pesquisa Agropecuária - (EMBRAPA) - Concórdia, SC \\ ${ }^{4}$ Instituto Federal de Educação Ciência e Tecnologia - Bagé, RS \\ ${ }^{5}$ Universidade Federal do Rio Grande - Rio Grande, RS
}

\begin{abstract}
The aim of this study was to evaluate the effect of replacing soybean meal with canola meal in broiler diets on performance, liver histopathology, morphometry of the intestinal mucosa and thyroid. One-day-old Cobb chicks $(n=300)$ were distributed in a completely randomized design, with increasing levels of replacement of soybean meal with canola meal $(0,25,50,75$ and 100\%) and 6 repetitions of 10 birds each. Weight gain decreased linearly $(\mathrm{P}<0.05)$ with increasing levels of inclusion of canola meal, in all stages. Villus height in the duodenum and jejunum linearly decreased $(\mathrm{P}<0.05)$. Follicle diameter and thyroid follicular epithelium height increased linearly with increasing levels of canola meal $(\mathrm{P}<0.05)$. Similarly, there was an increase in relative weight of liver and heart, and liver steatosis in the highest levels of replacement. In conclusion, the replacement of soybean meal with canola meal can reduce performance, adversely affecting the thyroid, liver and the morphometric characteristics in the duodenum and jejunum.
\end{abstract}

Keywords: nutrition, poultry, proteins, thyroid gland

\section{RESUMO}

O objetivo deste estudo foi avaliar o efeito da substituição do farelo de soja pelo farelo de canola na dieta de frangos de corte sobre o desempenho, a histopatologia hepática, a morfometria da mucosa intestinal e da tiroide. Foram distribuídos 300 pintos com um dia de idade em um delineamento inteiramente causualizado, com níveis crescentes de substituição do farelo de soja pelo farelo de canola (0, 25, 50, 75 e 100\%), 6 repetições com 10 aves cada. O ganho de peso diminuiu linearmente $(P<0,05)$ com níveis crescentes da substituição, em todas as fases. Assim como, a altura das vilosidades no duodeno e jejuno diminuiu linearmente $(P<0,05)$ em todas as idades avaliadas. O diâmetro do folículo e a altura do epitélio da tireoide aumentaram linearmente conforme aumentou os níveis de farelo de canola $(P<0,05)$. Da mesma forma, houve um aumento do peso relativo do fígado e do coração, $e$ aparecimento de esteatose hepática nos níveis mais altos de substituição. Em conclusão, a substituição do farelo de soja pelo farelo de canola pode reduzir o desempenho, afetando negativamente a tireoide, o fígado e as características morfométricas no duodeno e jejuno.

Palavras-chave: aves, glândula tireoidiana, nutrição, proteína

\section{INTRODUCTION}

The term canola is assigned to genetically improved varieties of rapeseed which contain less than $2 \%$ erucic acid and $30 \mu \mathrm{mol} / \mathrm{g}$ glucosinolates. These substances together with non-starch polysaccharides, tannins, sinapine, phytic acid are part of its anti-nutritional factors. Although the protein content is lower, its amino acid ratio is similar to that of soybean meal with lower content of lysine and higher of methionine and cysteine (Khajali and Slominski, 2012).

Recebido em 7 de abril de 2016

Aceito em 12 de abril de 2017

E-mail:p.agrnomia@gmail.com 
According to Tripathi and Mishra (2007), glucosinolate content above $8.0 \mu \mathrm{mol} / \mathrm{g}$ results in a lower growth rate. This is because glucosinolates, after ingestion, undergo a rearrangement to originate a range of products, including isothiocyanates, goitrins, nitriles, thiocyanates, which interfere with the functioning of the thyroid and negatively affect the performance (Tripathi and Mishra, 2007).

The highest concentration of tannins and fibers in the diet, due to the increased inclusion of canola meal, can lead to a decline in morphometry of the intestinal villi for complexing with proteins and carbohydrates. The intestinal mucus is a glycoprotein and can also bind to tannins. Consequently, there is a compensation of mucus secretion, which increases crypt depth in order to overcome this deficiency. In addition, tannin can complex with calcium and makes it unavailable for intestinal absorption and, consequently, for deposition in bones (Figueiredo et al., 2003). Thus, the aim of this study was to evaluate the performance, liver histology and morphometry of the intestinal mucosa and thyroid in broiler diets with canola meal.

\section{MATERIAL AND METHODS}

This research was approved by the Ethics Committee on Animal Experimentation of the Universidade Federal de Pelotas, under number 805. One-day-old Cobb chicks $(n=300)$, females and males, were housed. The experimental diets (Table 1) were prepared to meet the nutritional requirements at each stage of development, based on the recommendations of Rostagno et al. (2011). Five levels of replacement of soybean meal were tested $(0,25,50,75$ and $100 \%)$ with canola meal in the diet. Feed and water were provided ad libitum. Birds and feed leftovers were weighed to calculate the variables feed intake, weight gain and feed conversion (feed intake/weight gain) weekly.

At 21 and 42 days of age, four birds per treatment were fasted for 6 hours, individually weighed and euthanized. Heart and liver were weighed to calculate the relative weight of the organ: relative weight $=[$ (organ weight $/$ body weight of the bird)*100]. Approximately $2 \mathrm{~cm}$ long samples were taken from: duodenum (end of the duodenal loop); jejunum (from the distal duodenal loop to the Meckel's diverticulum) and ileum (anterior portion of the cecum).

At 42 days, the thyroid gland was collected for morphometric analysis and the right lower lobe of the liver was collected for histopathology, through single blind analysis. Samples were identified and immersed in $10 \%$ formaldehyde (buffered solution: $\mathrm{pH}$ 7.5). After 24h, samples were taken from formaldehyde and placed in $70 \%$ ethanol and then brought to the Histology Laboratory of the Universidade Federal do Rio Grande (Furg). After fixation, the specimens were dehydrated, cleared and embedded in automated vacuum tissue processor (ASP-200 LEICA, Germany) and embedded in paraplastXtra (SIGMA P3808). Blocks were sectioned in a motorized rotary microtome (LEICA RM-2050, Germany) to $5 \mu \mathrm{m}$ thickness. The slides were stained with hematoxylin and eosin (HE), followed by mounting between slide and cover slip in Entellan ${ }^{\circledR}$ resin (Merck). The measurements were made by the software Image $\mathbf{J}^{\mathbb{R}}$ in photos taken by digital camera Olympus DP-73, coupled to an Olympus BX-51 microscope. The variables studied were duodenal villus height, crypt depth, villus height/crypt depth ratio and the epithelium thickness. Measurements of villi were taken from the basal region coinciding with the upper portion of the crypts to the apex of the villi. Crypts were measured from their depth to the point of insertion of the villi, where debouch the crypts. Thyroid was analyzed for diameter of follicles and follicular epithelium height. A total of 10 measurements were taken from each bird, totaling 40 replicates per treatment and per age of the bird.

A completely randomized design was used with five treatments and six replications of 10 birds each. A polynomial regression analysis was used to predict the effect of replacing soybean meal with canola meal in broiler diets on performance, liver histopathology, morphometry of the intestinal mucosa and thyroid. Data were analyzed using the GLM procedure of the SAS program; the polynomial regression models were selected based on the significance of the regression coefficients $(\mathrm{P}<0.05)$ and on the value of the coefficient of determination. The maximum of the curve corresponding to the quadratic effect was then calculated for the observed variables. 
Table 1. Nutritional composition of the experimental diets at initial, growth and final stages

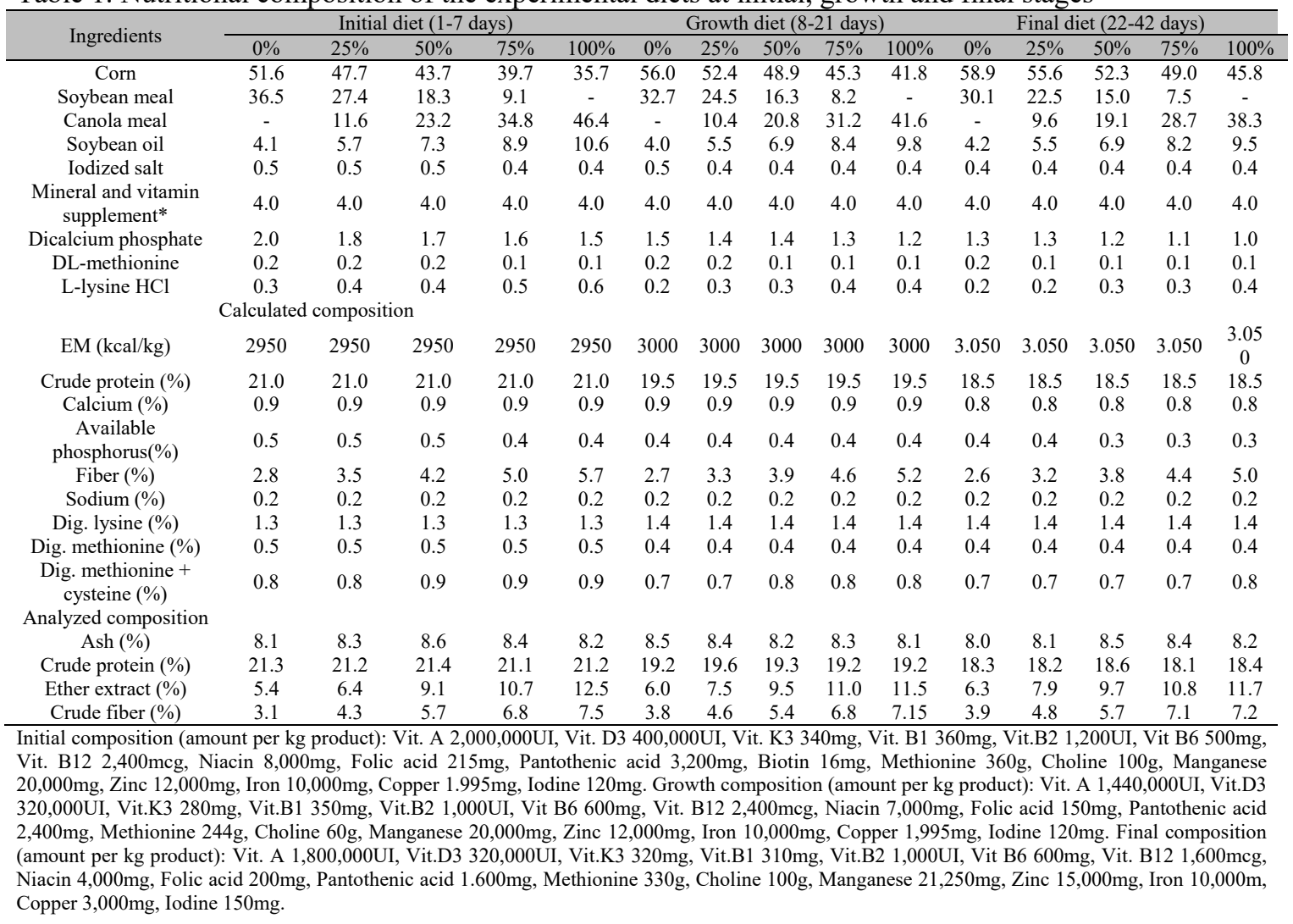

\section{RESULTS AND DISCUSSION}

Feed intake reduced linearly $(\mathrm{P}<0.05)$ with increasing levels of replacement of the soybean meal with canola meal from 8 to 14 days, and from 22 to 28 days. Accordingly, weight gain decreased linearly $(\mathrm{P}<0.05)$ in the first two weeks with increased levels of canola meal in the diet. In its turn, feed conversion worsed linearly $(\mathrm{P}<0.05)$ in the first week of replacement (Table 2). Unlike that observed from 22 to 28 days, when the feed conversion was improved. The reason is that in this week feed intake decreased but there was no reduction in weight gain. At the end of 42 days, the live weight of broilers reduced linearly $(\mathrm{P}<0.05)$ as the substitution of soybean meal with canola meal in the diet was increased.

absorption of lipids, once it reduces the emulsification of fat (Maiorka et al., 1997). The negative effect on broiler performance with increasing levels of replacement of soybean meal with canola meal can be mainly attributed to the poor performance in the early stages of the birds, because of both anti-nutritional factors of canola meal and the high levels of oil in the diet. At the end of the experiment, the live weight of the birds reduced linearly as the level of canola meal was increased. Because the bird life cycle is relatively fast, probably there was no time to recover, although weight gain from the $14^{\text {th }}$ day of age did not present statistical difference.

Studies on canola meal assign the lowest performance to the presence of a greater amount of fiber compared to soybean meal, which could reduce the digestibility of the diet (Gopinger et al., 2014; Naseem et al., 2006; Mikulski et al., 2012). In Table 1, it is possible to observe an increase in dietary fiber according to increasing levels of canola meal in the diet. According to Khajali and Slominski (2012), fiber of canola meal may contain up to $2.5 \%$ raffinose and stachyose, which are hygroscopic substances, capable of forming a gel in the digesta and preventing the action of digestive enzymes and consequently the absorption of nutrients by the gastrointestinal tract. 
Table 2. Weekly performance of broilers fed different levels of replacement of soybean meal with canola meal

\begin{tabular}{|c|c|c|c|c|c|c|c|c|c|c|}
\hline \multirow{2}{*}{ Days } & \multirow[b]{2}{*}{ Variables } & \multicolumn{5}{|c|}{ Replacement levels (\%) } & \multirow{2}{*}{$* P$} & \multirow{2}{*}{$\begin{array}{l}\text { CV } \\
(\%)\end{array}$} & \multirow{2}{*}{$\mathrm{R}^{2}$} & \multirow{2}{*}{ Equation } \\
\hline & & 0 & 25 & 50 & 75 & 100 & & & & \\
\hline \multirow{3}{*}{ I } & WG & 122 & 119 & 111 & 106 & 103 & 0.0015 & 6.9 & 0.97 & $y=122.45-0.201 x$ \\
\hline & FI & 143 & 145 & 139 & 135 & 142 & 0.4436 & 6.8 & & \\
\hline & $\mathrm{FC}$ & 1.17 & 1.22 & 1.25 & 1.27 & 1.37 & 0.0011 & 5.5 & 0.92 & $y=1.17+0.003 x$ \\
\hline \multirow{3}{*}{$\frac{ \pm}{\infty}$} & WG & 282 & 282 & 271 & 260 & 238 & 0.0005 & 8.1 & 0.89 & $y=288.52-0.44 x$ \\
\hline & FI & 364 & 367 & 356 & 333 & 339 & 0.0391 & 6.0 & 0.78 & $y=368.98-0.34 x$ \\
\hline & $\mathrm{FC}$ & 1.29 & 1.30 & 1.31 & 1.28 & 1.45 & 0.0799 & 9.9 & & \\
\hline \multirow{3}{*}{$\vec{\sim}$} & WG & 392 & 402 & 367 & 348 & 386 & 0.2138 & 11.0 & & \\
\hline & FI & 602 & 533 & 562 & 566 & 565 & 0.3367 & 9.8 & & \\
\hline & $\mathrm{FC}$ & 1.54 & 1.32 & 1.55 & 1.63 & 1.46 & 0.1562 & 10.3 & & \\
\hline \multirow{3}{*}{ 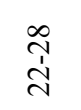 } & WG & 493 & 506 & 479 & 435 & 467 & 0.3077 & 12.4 & & \\
\hline & FI & 810 & 858 & 718 & 669 & 677 & 0.0003 & 11.4 & 0.74 & $y=837.47-1.82 x$ \\
\hline & $\mathrm{FC}$ & 1.65 & 1.71 & 1.50 & 1.54 & 1.45 & 0.0115 & 10.5 & 0.70 & $y=1.69-0.002 x$ \\
\hline \multirow{3}{*}{$\begin{array}{l}\text { m } \\
\text { ते }\end{array}$} & WG & 698 & 691 & 698 & 679 & 632 & 0.2952 & 8.7 & & \\
\hline & FI & 1133 & 1122 & 1105 & 1060 & 1126 & 0.508 & 7.0 & & \\
\hline & $\mathrm{FC}$ & 1.65 & 1.62 & 1.58 & 1.56 & 1.78 & 0.1667 & 9.6 & & \\
\hline \multirow{4}{*}{$\begin{array}{c}\text { f } \\
\text { bo }\end{array}$} & WG & 611 & 514 & 544 & 594 & 564 & 0.2988 & 14.6 & & \\
\hline & FI & 1129 & 1128 & 1131 & 1162 & 1129 & 0.9362 & 7.2 & & \\
\hline & $\mathrm{FC}$ & 1.86 & 2.04 & 2.19 & 1.95 & 2.02 & 0.4444 & 10.4 & & \\
\hline & LW & 2577 & 2623 & 2550 & 2504 & 2386 & 0.0245 & 5.1 & 0.97 & $y=2632-2.031 x$ \\
\hline
\end{tabular}

$* \mathrm{P}=$ significance level by the fitted polynomial regression. $\mathrm{WG}=$ weight gain $(\mathrm{g}), \mathrm{FI}=$ feed intake $(\mathrm{g}), \mathrm{FC}=$ feed conversion; $\mathrm{LW}=$ live weight; $\mathrm{CV}(\%)=$ coefficient of variation. $\mathrm{R}^{2}=$ coefficient of determination.

In order for the diets to be isocaloric, the oil level had to be increased as the replacement between meals increased as well (Table 1), since the canola meal has a lower metabolizable energy than soybean meal. In the first days of life of poultry, the enterohepatic system is still immature and can adversely affect the

The relative heart weight increased linearly with the replacement $(\mathrm{P}<0.05)$ at 42 days of age (Table 3). Naseem et al. (2006) and Woyengo et al. (2011) also found a higher relative weight of the heart when the levels of canola in the diet were increased. Possibly, the erucic acid in the meal may have caused an accumulation of fat in the heart muscle (Khajali and Slominski, 2012). Likewise, the relative liver weight increased with increasing levels of canola meal, at 21 and 42 days of age, similar to results presented by Payvastagan et al. (2012); Taraz et al. (2006) and Woyengo et al. (2011), which claimed that hypertrophy of the liver can be associated with the metabolism of glucosinolates. Gharaghami et al. (2008) worked with gamma irradiation on canola meal and decreased the concentration of glucosinolates in the diet, and found a better growth performance and lower relative liver weight compared to broilers fed untreated canola meal.

Table 3. Absolute weight ( $\mathrm{g})$ and relative weight $(\%)$ of the heart and liver of broilers fed increasing levels of replacement of soybean meal with canola meal

\begin{tabular}{|c|c|c|c|c|c|c|c|c|c|c|}
\hline \multirow{2}{*}{ Variables } & \multirow{2}{*}{ Days } & \multicolumn{5}{|c|}{ Replacement levels (\%) } & \multirow{2}{*}{ *p } & \multirow{2}{*}{ CV (\%) } & \multirow{2}{*}{$\mathrm{R}^{2}$} & \multirow{2}{*}{ Equation } \\
\hline & & 0 & 25 & 50 & 75 & 100 & & & & \\
\hline HW & 21 & 5.91 & 5.97 & 5.68 & 5.45 & 5.75 & 0.8214 & 10.70 & & \\
\hline (g) & 42 & 11.38 & 14.62 & 14.09 & 17.99 & 18.66 & 0.0440 & 20.03 & 0.9 & $y=9.06+1.79 x$ \\
\hline RHW & 21 & 0.78 & 0.82 & 0.76 & 0.85 & 0.87 & 0.3941 & 13.95 & & \\
\hline$(\%)$ & 42 & 0.48 & 0.56 & 0.59 & 0.78 & 0.76 & 0.0287 & 19.63 & 0.89 & $y=0.40+0.078 x$ \\
\hline LW & 21 & 21.36 & 23.63 & 23.05 & 23.22 & 23.45 & 0.5804 & 13.10 & & \\
\hline (g) & 42 & 44.81 & 42.31 & 46.3 & 48.03 & 53.59 & 0.0290 & 10.32 & 0.75 & $y=40.02+2.33 x$ \\
\hline RLW & 21 & 2.82 & 3.21 & 3.08 & 3.63 & 3.53 & 0.0017 & 9.99 & 0.77 & $y=2.70+0.184 x$ \\
\hline$(\%)$ & 42 & 1.86 & 1.66 & 1.96 & 2.07 & 2.21 & 0.0090 & 11.14 & 0.71 & $y=1.61+0.111 x$ \\
\hline
\end{tabular}

$* \mathrm{P}=$ significance level by the fitted polynomial regression. $\mathrm{CV}(\%)=$ coefficient of variation. $\mathrm{R}^{2}=$ coefficient of determination. $\mathrm{HW}=$ heart weight, $\mathrm{RHW}=$ relative heart weight, $\mathrm{LW}=$ liver weight, $\mathrm{RLW}=$ relative liver weight. 


\section{Growth performance...}

However, the histopathological analysis (Figure 1) showed that broilers fed diets with higher levels of canola meal had hepatic steatosis. The intracytoplasmic accumulation of triglycerides in hepatocytes occurs when the metabolic degradation capacity of the liver or the release of lipoprotein is impaired (Cullen 2009).

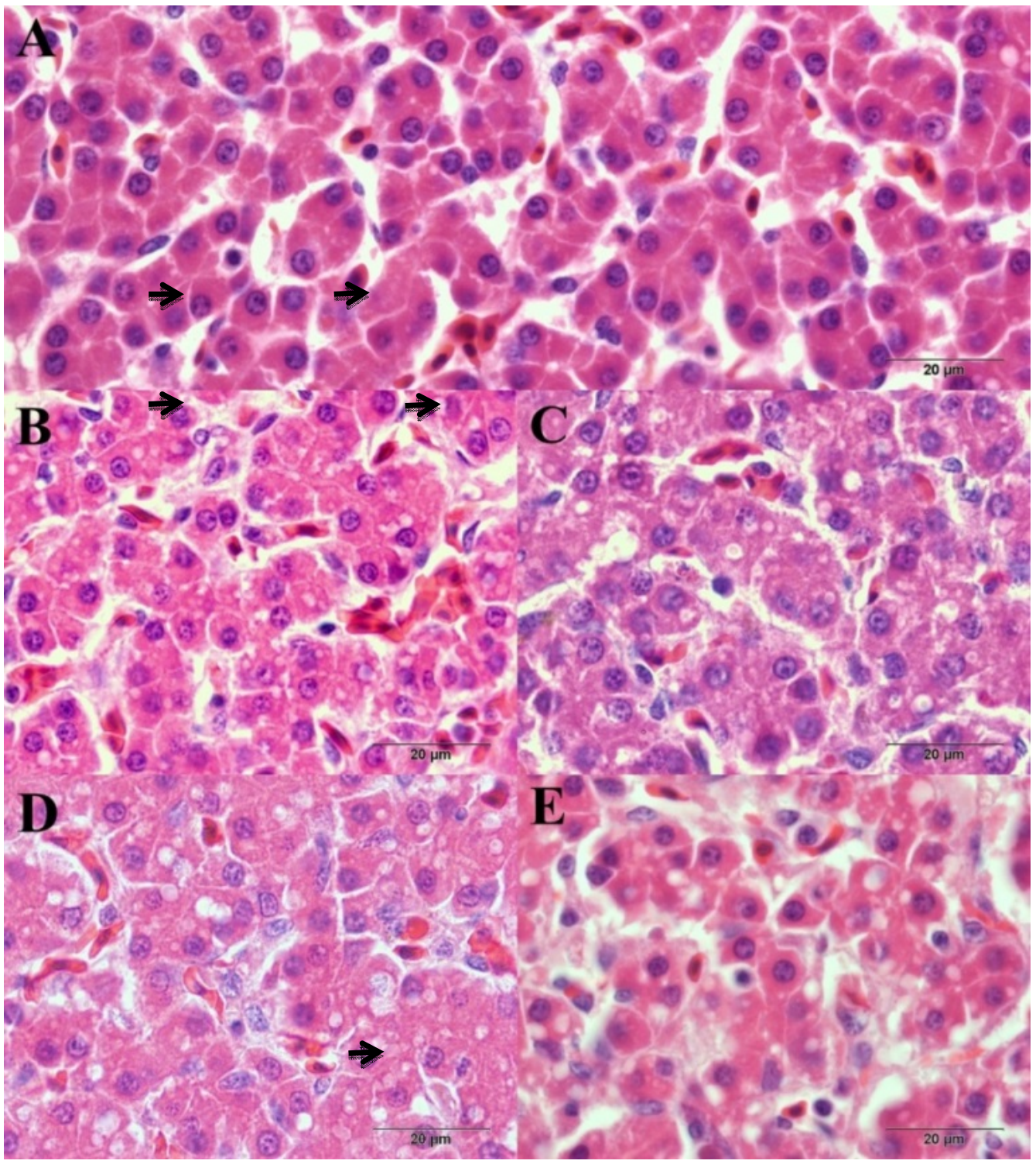

Figure 1. Microscopy of the liver (scale with $20 \mu \mathrm{m})$. A) control diet without replacement of soybean meal with canola meal; B) diet with 25\% replacement; C) diet with 50\% replacement; D) diet with $75 \%$ replacement; and E) diet with 100\% replacement. Indicates the presence of diffuse microvesicular steatosis.

In this work, the increase in the relative liver weight was due to the accumulation of fat in hepatocytes, and a hepatic overhead due to the metabolism of glucosinolates present in canola, impairing the lipid transport from the liver. The accumulation of lipids in hepatocytes may occur due to an imbalance in triglyceride turnover, resulting in increased hepatic flow of fatty acids from the diet and, in contrast, by the inefficient oxidation and transport of hepatic lipids (Cai and Yuan, 2005). 
The increase in liver size and consequently its metabolic activities implies increasing the use of dietary energy for maintenance instead of using it for growth, reducing the production of net energy, which would corroborate with a lower performance of broilers (Woyengo et al., 2011)

In the duodenum and jejunum a significant linear reduction in the villus height with increasing levels of canola meal was observed at both ages, thus increasing linearly the depth of the crypts and consequently decreasing the villus height: crypt depth ratio linearly as well (Table 4). The height of the epithelium increased significantly with increasing levels of canola meal in the diet, at 21 days of age. Unlike that registered in the ileum, with an increasing linear response in villus height $(\mathrm{P}<0.05)$ as increased the level of canola meal in the diet.

Table 4. Morphometry of duodenum, jejunum and ileum of broilers at different ages according to the replacement levels of soybean meal with canola meal

\begin{tabular}{|c|c|c|c|c|c|c|c|c|c|c|}
\hline \multirow{2}{*}{\multicolumn{2}{|c|}{$\begin{array}{c}\text { Variables } \\
(\mu \mathrm{m})\end{array}$}} & \multicolumn{5}{|c|}{ Replacement levels (\%) } & \multirow{2}{*}{$* \mathrm{P}$} & \multirow{2}{*}{ CV $(\%)$} & \multirow{2}{*}{$\mathrm{R}^{2}$} & \multirow{2}{*}{ Equation } \\
\hline & & 0 & 25 & 50 & 75 & 100 & & & & \\
\hline \multirow{4}{*}{$\begin{array}{l}\vec{\nabla} \\
\vec{\sim} \\
\vec{g}^{\prime} \\
\stackrel{\Xi}{\Xi}\end{array}$} & Villus & 1015 & 997 & 973 & 962 & 874 & 0.0066 & 18.06 & 0.84 & $y=1027.73-1.269 x$ \\
\hline & Crypt & 150 & 153 & 158 & 160 & 167 & 0.0044 & 17.51 & 0.96 & $y=149.57+0.159 x$ \\
\hline & $\mathrm{VH} / \mathrm{CD}$ & 7.6 & 7.3 & 6.6 & 6.4 & 6.4 & $<0.0001$ & 22.42 & 0.86 & $y=7.48-0.012 x$ \\
\hline & Epithelium & 21 & 21 & 22 & 26 & 27 & $<.00001$ & 11.24 & 0.93 & $y=19.91+0.067 x$ \\
\hline \multirow{4}{*}{ 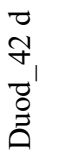 } & Villus & 1621 & 1462 & 1342 & 1274 & 1120 & $<0.0001$ & 13.41 & 0.98 & $y=1601.50-4.758 x$ \\
\hline & Crypt & 154 & 163 & 174 & 183 & 213 & $<0.0001$ & 18.26 & 0.92 & $y=149.71+0.554 x$ \\
\hline & $\mathrm{VH} / \mathrm{CD}$ & 11.1 & 9.3 & 8.0 & 7.4 & 5.4 & $<0.0001$ & 25.98 & 0.97 & $y=10.88-0.053 x$ \\
\hline & Epithelium & 22 & 23 & 22 & 22 & 23 & 0.3402 & 14.99 & & \\
\hline \multirow{4}{*}{ 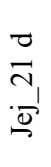 } & Villus & 1059 & 1040 & 988 & 908 & 898 & $<0.0001$ & 16.63 & 0.95 & $y=1069.42-1.816 x$ \\
\hline & Crypt & 177 & 185 & 206 & 208 & 250 & $<0.0001$ & 16.71 & 0.89 & $y=171.67+0.672 x$ \\
\hline & $\mathrm{VH} / \mathrm{CD}$ & 6.5 & 6.0 & 5.0 & 4.7 & 3.7 & $<0.0001$ & 23.75 & 0.96 & $y=6.52-0.027 x$ \\
\hline & Epithelium & 19 & 19 & 18 & 16 & 15 & $<0.0001$ & 17.77 & 0.98 & $y=19.54-0.044 x$ \\
\hline \multirow{2}{*}{$\underset{\mathrm{I}}{\mathrm{I}}$} & Villus & 1026 & 996 & 943 & 846 & 828 & $<0.0001$ & 17.94 & 0.95 & $y=1037.32-2.185 x$ \\
\hline & Crypt & 134 & 141 & 173 & 179 & 186 & $<0.0001$ & 18.54 & 0.91 & $y=134.19+0.563 x$ \\
\hline \multirow{2}{*}{ - } & $\mathrm{VH} / \mathrm{CD}$ & 8.0 & 7.4 & 5.6 & 5.2 & 4.8 & $<0.0001$ & 20.36 & 0.93 & $y=7.93-0.0354 x$ \\
\hline & Epithelium & 19 & 19 & 18 & 18 & 20 & 0.1149 & 16.62 & & \\
\hline \multirow{4}{*}{$\begin{array}{l}\vec{\beth}_{1} \\
\vec{\sim}_{1} \\
\Xi_{\Xi}\end{array}$} & Villus & 365 & 385 & 394 & 401 & 425 & $<0.0001$ & 10.17 & 0.96 & $y=367.13+0.541 x$ \\
\hline & Crypt & 115 & 104 & 102 & 107 & 114 & $<0.0001$ & 11.28 & 0.97 & $y=114.37-0.48 x+0.004 x^{2}$ \\
\hline & $\mathrm{VH} / \mathrm{CD}$ & 3.2 & 3.8 & 4.0 & 3.7 & 3.8 & $<0.0001$ & 18.23 & 0.69 & $y=3.31+0.019 x-0.0002 x^{2}$ \\
\hline & Epithelium & 25 & 22 & 17 & 26 & 29 & $<0.0001$ & 18.98 & 0.73 & $y=24.56-0.223 x+0.002 x^{2}$ \\
\hline \multirow{4}{*}{ 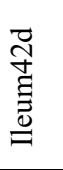 } & Villus & 523 & 556 & 582 & 586 & 600 & $<0.0001$ & 10.57 & 0.91 & $y=532.46+0.736 x$ \\
\hline & Crypt & 159 & 139 & 129 & 138 & 163 & $<0.0001$ & 10.18 & 0.99 & $y=159.24-1.19 x+0.012 x^{2}$ \\
\hline & $\mathrm{VH} / \mathrm{CD}$ & 3.4 & 4.0 & 4.5 & 4.3 & 3.7 & $<0.0001$ & 13.12 & 0.98 & $y=3.33+0.041 x-0.0004 x^{2}$ \\
\hline & Epithelium & 21 & 25 & 25 & 27 & 30 & $<0.0001$ & 15.02 & 0.93 & $y=21.72+0.007 x$ \\
\hline
\end{tabular}

$* \mathrm{P}=$ significance level by the fitted polynomial regression. $\mathrm{CV}(\%)=$ coefficient of variation. $\mathrm{R}^{2}=$ coefficient of determination

The crypt depth showed a quadratic response, reducing up to levels of $60 \%$ and $49.58 \%$ of replacement, for 21 and 42 days, respectively. The villus height: crypt depth ratio showed a similar response, increasing up to levels of $47.8 \%$ and $51.25 \%$ of replacement, for 21 and 42 days, respectively.

Crypt depth is indicative of the compensatory capacity or hyperplasia of epithelial cells due to a higher level of aggression to the morphological structure of the intestinal mucosa caused by anti-nutritional factors. The increased in desquamation results in increased crypt depth to ensure adequate cell renewal and replacement of cell losses in the apical region of the villi (Oetting et al., 2006). In this way, the negative effect of canola meal on villus height: crypt depth ratio in both duodenum and jejunum, may have contributed to the impairment of animal performance, since the higher the ratio the better the absorption of nutrients and the smaller the losses of energy with cell renewal (Figueiredo et al., 2003). 
The duodenum and jejunum respond more sharply to aggression and mucosal stimulation than the ileum, which may explain the differences found between these segments. Upon arriving at the ileum the fecal bolus have been through a high enzyme activity in this segment, the $\mathrm{pH}$ is more stable and has less nutrients to absorb causing a less aggressiveness to the intestinal mucosa (Campos et al., 2007).

In the thyroid, both the follicle diameter and the epithelial height showed an increasing linear correlation $(\mathrm{P}<0.05)$ with increasing levels of substitution of soybean meal with canola meal (Figure 2).

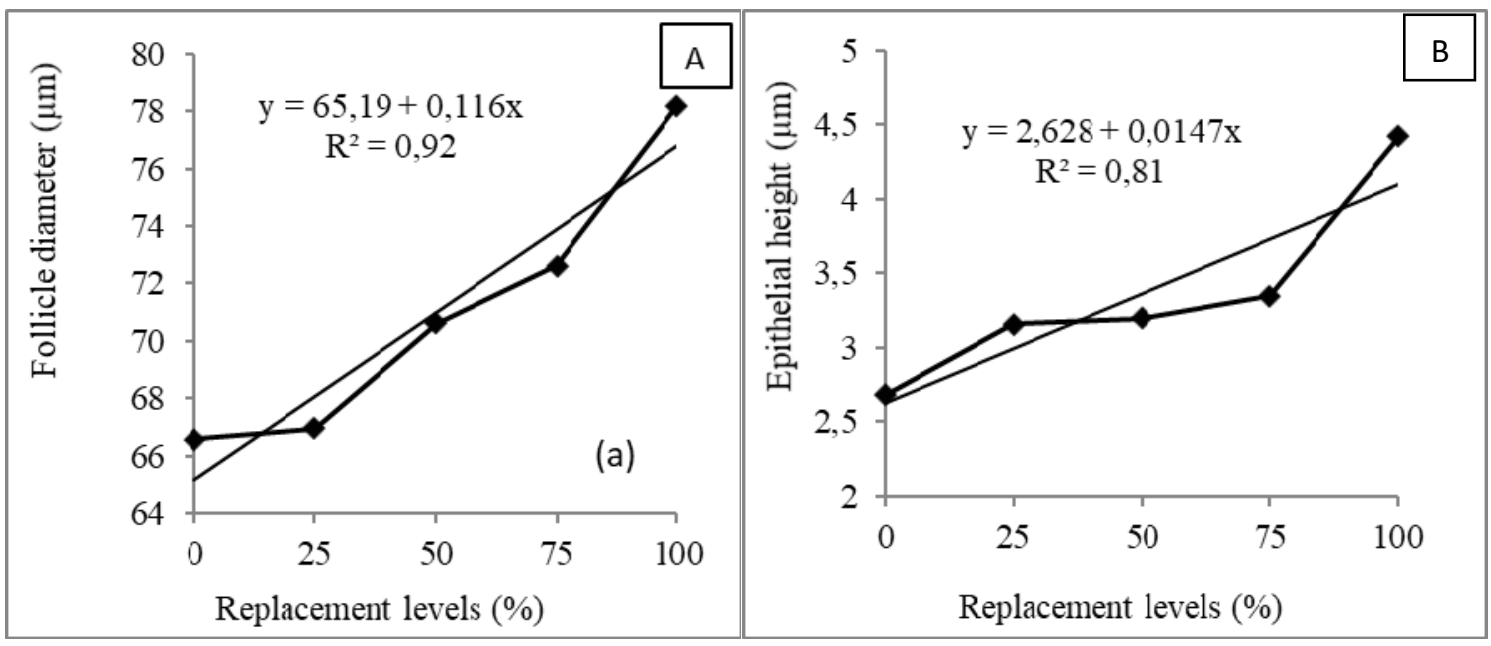

Figure 2. Histology of thyroid follicle diameter of variables A) and epithelial height B) according to the replacement level of soybean meal with canola meal.

Rachid et al. (2001) analyzed a T-2 toxin, which as well as the glucosinolate is also a goitrogen, and observed an increased diameter of follicles that had the lumen filled with a large amount of colloid, characterizing goitre. Similar findings were registered herein, in which possibly goitrogens and glucosinolates caused an increase in epithelial height and follicle diameter.

In the thyroid, the size of follicular cells varies according to the activity of the gland. Tissue morphology is readily modulated by the functional state of the gland, predominantly controlled by pituitary thyroid stimulating hormone (TSH). Thus, in hypothyroidism, the gland receives great stimulus from pituitary TSH and there is hypertrophy of the follicular epithelium, which starts to show a cylindrical shape, and may even present hyperplastic tissue response (Kimura, 2012)

\section{CONCLUSIONS}

The replacement of soybean meal with canola meal in broiler diets negatively affected the growth performance and may interfere with the viability of the superficial mucosa. The effects on the liver and thyroid evidenced that canola contains glucosinolate levels that can adversely affect broilers.

\section{REFERENCES}

CAI, D.; YUAN, M. Local and systemic insulin resistance resulting from hepatic activation of IKK-beta and NF-Kappa B. Nat. Med., v.11, p.183-905, 2005.

CAMPOS, D.M.; FILHO, F.; FURLAN, K.A.A.; MACARI, M. Desenvolvimento da mucosa intestinal e a substituição do milho por sorgo na dieta de pintainhos de corte. Rev. Bras. Ciênc. Vet., v.5, p.44-48, 2007. 
CULLEN, J.M. summary of the world small animal veterinary association standardization committee guide to classification of liver disease in dogs and cats. Vet. Clin. Small Anim., v.39, p.395-418, 2009.

FIGUEIREDO, D.; MURAKAMI, M.; PEREIRA, A. et al. Desempenho e morfometria da mucosa de duodeno de frangos de corte alimentados com farelo de canola, durante o período inicial. Rev. Bras. Zootec., v.32, p.1321132, 2003.

GHARAGHAMI, H.; ZAGHARI, M.; SHAHHOSSEINI, G. et al. Effect of gamma irradiation on anti-nutritional factors and nutritional value of canola meal for broiler chickens. Asian Aust. J. Anim., v.21, p.14791485, 2008.

GOPINGER, E.; XAVIER, E.G.; ELIAS, M.C. et al. The effect of different dietary levels of canola meal on growth performance, nutrient digestibility, and gut morphology of broiler chickens. Poult. Sci. v.93, p.1130-1136, 2014.

KHAJALI, F.; SLOMINSKI, B.A. Factors that affect the nutritive value of canola meal for poultry. Poult. Sci., v.9, p.2564-2575, 2012.

KIMURA, E. Glândula tireoide. In: AYRES, M.M. Fisiologia. 4.ed. Rio de Janeiro: Guanabara Koogan, 2012. p.1055-1079.

MAIORKA, A.; LECZNIESKI, J.; BARTELS, H.A. Efeito do nível energético da ração sobre o desempenho de frangos de corte de 1 a 7, 7 a 14, 14 a 21 dias de idade. In: CONFERÊNCIA APINCO DE CIÊNCIA E TECNOLOGIA AVÍCOLAS, 1997, Campinas. Anais... Campinas: Fundação Apinco de Ciência e Tecnologia Avícolas, 1997. p.18.

MIKULSKI, D.; JANKOWSKI, J.; ZDUNCZYK, Z. et al. B. The effect of different dietary levels of rapeseed meal on growth performance, carcass traits, and meat quality in turkeys. Poult. Sci., v.91, p.215-223, 2012.
NASEEM, M.; KHAN, S.; YOUSAF, M. Effect of different levels of canola meal on broiler production performance during two phases of growth. Pak. Vet. J., v.26, p.129-134, 2006.

OETTING, L.; UTYAMA, C.E.; GIANI, P. et al. Efeitos de extratos vegetais e antimicrobianos sobre a digestibilidade aparente e o desempenho a morfometria dos órgãos e a histologia intestinal de leitões recém-desmamados. Rev. Bras. Zootec., v.35, p.1389-1397, 2006.

PAYVASTAGAN, S.; FARHOOMAND, P.; SHAHROOZE, R. et al. The effects of different levels of canola meal and copper on performance susceptibility to ascites and plasma enzyme activities in broiler chickens. Ann. Biol. Res. v.4, p.5252-5258, 2012.

RACHID, M.A.; NUNES, V.A.; SERAKIDES, R. et al. Histomorfometria e função da tireoide de frangos de corte após a ingestão de toxina T-2 de Fusariumsporotrichioides. Arq. Bras. Med. Vet. Zootec., v.53, p.66-70, 2001.

ROSTAGNO, H.S.; ALBINO, L.F.T.; DONZELE, J.L. et al. Tabelas brasileiras para aves e suínos: composição de alimentos $\mathrm{e}$ exigências nutricionais. Viçosa: Federal University Viçosa, 2011. 186p.

TARAZ, Z.; JALALI, S.; RAFEIE, F. Effects of replacement of soybean meal with rapeseed meal on organs weight some blood biochemical parameters and performance of broiler chicks. Intern. J. Poult. Sci., v.5, p.1110-1115, 2006.

TRIPATHI, M.K.; MISHRA, A.S. Glucosinolates in animal nutrition: a review. Anim. Feed Sci. Tech., v.132, p.1-27, 2007.

WOYENGO, T.A.; KIARIE, E.; NYACHOTI, C.M. Growth performance, organ weights, and blood parameters of broilers fed diets containing expeller-extracted canola meal. Poult. Sci., v.90, p.2520-2527, 2011. 